\title{
Kierkegaard as Feuilleton Writer
}

G eorge Pattison

King's College, Cambridge

The writer and dramatist $\mathrm{H}$ enrik $\mathrm{H}$ ertz, who was both a contemporary of Kierkegaard's and knew him socially, once noted in hisjournal that «S. Kierkegaard often seems to me - although only in his humorous writings- to be nothing other than a very tal ented and well-read feuilleton writer... $\mathrm{H}$ is style is altogether that of a feuilleton writer, not exactly of the French style but a mixture of Jules Janins and a young, philosophically educated German.»

The remark is in itself somewhat slight and does not belong to any sustained discussion of Kierkegaard's literary significance - nor is it even clear what $\mathrm{H}$ ertz means by Kierkegaard's humorous writings: the pseudonyms, or only some of them, and, if so, which? But although it would be extremely rash, foolish even, to make this passing comment the basis for a new reading of Kierkegaard's entire authorship, it does illuminate that authorship from an unusual angle. $\mathrm{N}$ or is this illumination merely literary. If H ertz's own interest in Kierkegaard probably did not extend to the philosophical content of his works, his comment is not without implications for a contemporary philosophical reader. Let us see how this might be so.

But first we have to identify what exactly $\mathrm{H}$ ertz meant by a «feuilleton writer».

Feuilleton literature was (and, one might say, still is) a genre of journalistic writing, aspiring to reflect and, in reflecting, to mould the point of view of a public that aspires to be both fashionable and cultured. Undoubtedly it would have been regarded by someone like H ertz as operating on a lower level than the kind of criticism emanating from the circle of writers, artists and intellectuals gathered around the dramatist, critic and amateur philosopher J.L. Heiberg, a circle with which both $\mathrm{Hertz}$ and Kierkegaard had some association.

At one level it immediately becomes obvious that $K$ ierkegaard was a writer of a quite different stamp from that of the typical feuilleton writer. But although his critical sophistication and religious and philosophical passions put 
him in another class from Carstensen and Rosenhoff, he did share many of their cultural horizons ${ }^{2}$. If K ierkegaard is now categorized as belonging to the world of «high» culture and if, even in his own day, he could be identified as a part of the cultural élite, the «public» addressed by the feuilleton writers often attended the same plays, read the same books, listened to the same music and looked at the same paintings as those who prided themselves on a more critical and less dilettante approach. The difference was not so much in what was seen (heard, etc.), but in how it was seen.

An example of the interweaving of these two worlds in the body of K ierkegaard's authorship is provided by the extended review essay Kierkegaard wrote about Augustin Eugène Scribe's comedy T heFirst L ove, included in the writings of the aesthete A that make up Part I of Either/Or. Scribe is, it has to be said, almost universally forgotten today, but in his own time he was Europe's most successful dramatist. Carstensen's Figaro noted that in one year Scribe had earned more money than all other French dramatists put together. H is plays were also an important ingredient in H eiberg's campaign to introduce a more Francophile tone into D enmark's theatrical life: between 1823 and 1895, one hundred and one plays by Scribe were performed 2976 times at the Theatre Royal in Copenhagen. Indeed, $\mathrm{H}$ eiberg himself translated a number of these, including The First L ove.

Although K ierkegaard makes it clear that TheFirst L ove is little more than a light comedy, playing upon the triviality of its characters' emotional involvements, he insists that, within the limits of its genre it is a masterwork of irony and reflection, making much ado about what is in itself nothing, a comedy of pure error.

This appraisal of The First L ovewas, in turn, one of the features of Either/O $\mathrm{r}$ that irritated $\mathrm{H}$ eiberg when he came to review it in his journal Intelligensolade. $\mathrm{H}$ eiberg wrote that the author of Either/O $\mathrm{r}$ had 'made a masterpiece out of a pretty little bagatelle and ascribes to it a tendency which is virtually the opposite of what Scribe admits to ${ }^{3}$. For his part, K ierkegaard was furious about $H$ eiberg's review and filled pages of his journal with sarcastic remarks about the man who was regarded as the greatest authority in D anish letters, and from whom Kierkegaard had expected a more insightful judgement.

Curiously, Intelligensbladealso included a small piece by $\mathrm{H}$ ertz relating to The Peep Show, that Kierkegaard regarded it as an important parable about the nature of the modern public (SV3 14, 85) and was only sorry that H ertz,

2. It is plausible that the experimental pseudonym Lt. Rosenpind (or, Rosenblad) associated with an extensive group of notes for an uncompleted work called «Writing Sampler»simultaneously satirizes $\mathrm{C}$ arstensen and Rosenhoff ( $\mathrm{C}$ arstensen was regularly referred to by his military rank) - one of the notes simply has «Feuilleton» as a heading. An article sometimes believed to be by K ierkegaard and entitled «Literary Q uicksilver or an Attempt at the $\mathrm{H}$ ighest $\mathrm{M}$ adness together with Lucida Intervalla did appear» in Carstensen's $\mathrm{N}$ y Portefeuille, although it was very possibly by K ierkegaard's then secretary P. W. Christensen. (See Pap. IV A, 141.)

3. H EIBERG, J. L. (1843), p. 290. 
in defending it against his detractors, had called it a «mere bagatelle». (Pap VII B 125,87$)$ This is striking in view of H eiberg's use of the self-same expression in reviewing Either/O $\mathrm{r}$, and it is doubly interesting in that $\mathrm{H}$ ertz did not himself use it. H e did refer to it as «a small, light piece» - but it was once again H eiberg who called it a «bagatelle»! Kierkegaard's slip (several years after H eiberg's review of Either/O $r$ ) is indicative of how deeply H eiberg's words had wounded him.

We may seem to be descending into the absolute trivia of K ierkegaardiana, but the example is not uninteresting in the light of H ertz's own comments about the typical style of the feuilleton writer, in words qualifying his previously quoted remark about Kierkegaard: «he takes his time, letting his pen run fast and loose, makes flies into elephants and vice versa and lets his main emphasis fall on the piquant presentation of the subject and often, even, on the very bizarreness of the idea ${ }^{4} . » T$ he debate about T he First Love and The Peep Show illustrates the critical consequences of this, since the key issue was precisely that of proportion, with the accusation flying backwards and forwards that one or other critic has lost all sense of proportion, making a masterpiece out of a bagatelle, an elephant out of a fly and, to cut a long story short, much ado about nothing. But this in turn highlights a further feature of critical writing in the zone of cultural life traversed both by the feuilleton writers and by critics of a more reflective kind - a feature perhaps not accidentally linked to the title of $\mathrm{H}$ ertz's little piece (Perpektivkassen) - that everything depends on perspective or point of view. The aim of the feuilleton writer is, above all, to direct the reader's gaze in the midst of the ever-changing caleidoscope of cultural life.

In his study Techniques of the $O$ bserver Jonathan C rary has argued that the period in which Kierkegaard developed towards his mature authorship was one that marked the emergence of «a new kind of observer». N ew optical technology, simultaneously exploited in the worlds of science and industry, medicine and popular entertainment, gave a hitherto unprecedented importance to the perceiving subject in determining how the world looked, a development reflected in the culture of spectatorship that grew up in the nineteenth century, as evidenced by the rise of museums, arcades, zoos and pl easure parks, together with photography, steroscopy, dioramas and, at the end of the century, the cinemas.

It is no coincidence in this context that $C$ arstensen, one of the moving spirits of feuilleton literature in D enmark in the early 1840s, should also be the founder of Denmark's best-known pleasure park, the mould-breaking Tivoli Gardens. H ere the public could experience for themsel ves the kind of leisurely spectatorship that had previously been the preserve of English M ilords on the Grand Tour. Behind the scenes, however, was the critic, the one who not only directed the gaze of the public but who could abruptly invoke a shift

5. See CrARY, J. (1990); also ZerLAN G, M. (1995). 
of view-point, turning masterpieces back into bagatelles and elephants back into flies. In such a situation the world of culture is no longer the world shaped by classical aesthetic values in which beauty is truth and truth beauty in everlasting self-sameness and self-sufficiency. Everything has now become ephemeral, volatile, infinitely adaptable and manipulable. It is the world of the fugitive and the transient, the popular and the relative, a world in which triviality and bathos have as much claim upon aesthetic validity as the good, the true and the beautiful. It is in short, the world of popular fashionable culture.

W hat it is like to live in such a world is succinctly captured by K ierkegaard in a jotting from his early journals: « should like to write a novel, in which the main character should be a person who had acquired a pair of glasses, of which the one glass made everything as small as an oxy-gas-microscope, the other made everything larger in the same degree, [so that] he experienced everything very relativistically.» (Pap. II A, 203) - An experience with which we, one hundred and fifty years later, have learned to make into a way of life.

$H$ ertz's description thus highlights an important aspect of Kierkegaard's work that has been almost entirely neglected in the secondary literature and obscured by the image of Kierkegaard as a gloomy and solitary figure. For Kierkegaard did not write in some ivory tower, untouched by the currents of contemporary popular culture but he was, on the contrary, engaged with that culture in a multitude of ways, ways it has only been possible to touch on here $e^{6}$.

This also has, as I suggested at the beginning, implications for the philosophical reading of Kierkegaard. H ow so?

It is customary to see Kierkegaard's place in the history of ideas in terms of his affiliation to what might, following Leavis, be called, the Great Tradition, or, perhaps, the «C anon» of Philosophical Classics: Plato, Aristotle, Augustine, D escartes, Kant, H egel, etc. - or in terms of his influence upon the further development of that Tradition in $\mathrm{N}$ ietzsche, $\mathrm{H}$ eidegger and twentieth century existentialist philosophy. Even if the attempt to contextualize his work by such comparisons culminates in the judgement that heis, at best, a marginal contributor to the $G$ reat Tradition (or even the joker in the pack), the comparison itself serves to give the interpretation of his work a certain philosophical dignity.

This approach is not without merit. Clearly K ierkegaard did engage with the $G$ reat Tradition at a variety of levels, bringing his own insights and formulations to the ongoing debate about a number of fundamental questions in philosophy. But, importantly, the material of his own philosophizing was not restricted to the topoi of classical philosophical texts but was drawn no less frequently from the ephemeral world of popular culture, the world reflected in the pages of the feuilleton literature. In this respect Kierkegaard was a man of the modern urban world in a way that more academic thinkers such 
as $\mathrm{H}$ ege (or, for that matter, Feuerbach or Strauss, whose ideal was that of the academy even when they no longer belonged to it) could ever be.

This, of course, raises an immediate problem for our interpretation of Kierkegaard. M any of the manifold connections between his authorship and the world of the feuilleton writers have, in the nature of the case, vanished into obscurity. A critical discussion of $\mathrm{H}$ egel's category of transition, conducted with the help of Aristotleand Trendelenburg, will necessarily have a relatively timeless quality that a debate about whether a one-act comedy sketch (not even included in standard editions of its author's selected works) is or is not «a bagatelle» can never hope to attain. We (or the philosophers amongst us) still have a context in which to understand the former, whereas the latter will be accesible only to a cultural archeologist of extremely narrow interests. W hat is ephemeral vanishes with the passing of its day, and the day of the popular culture of the 1840s has well and truly passed.

This introduces a far-reaching distortion into our reading of K ierkegaard. O nly a small minority of Kierkegaard readers (even of Danish-reading Kierkegaard readers) will be committed to the labour of reconstructing the interactions between his writing and the world of the then popular culture. But it is important, very important, for all philosophically interested readers of K ierkegaard to recognize that those connections arethere. For Kierkegaard's critique of the Great Tradition is not merely internal. It is a critique of the whole academic style. As K ierkegaard's most esteemed role model, Socrates, sought to philosophize in the market-place, so he himself sought to practice both philosophy and Christian testimony in the midst of the contemporary equivalent of the forum - the «public» domain addressed by popular journalism. Nor is this simply the manifestation of a personal preference for the populist over the scholarly approach to philosophy. Rather, it is rooted in a sense that the tradition itself has entered into a critical and potentially terminal phase in the situation of modernity, a situation of which the rise of popular culture, an essential and paradigmatic phenomenon of modern urbanity, is a powerfully expressive symptom.

If we wish to promote philosophy à la K ierkegard, then, we should be wary of attempting to justify his work by elevating him into the ranks of the «Classics». K ierkegaard is not just a debating partner for $\mathrm{H}$ egel and $\mathrm{C} 0$. $\mathrm{He}$ is also one of the first to have alerted us to the fact that it is the representations of value in popular culture that have the most immediate impact on our perception of what makes for a worthwhile life, and that such perceptions shape even the prejudices of philosophers, for philosophers too participate in this culture which is the all-pervading medium of modern life. There is therefore an important critical task to be performed in learning to distinguish between what is 'a mere bagatelle' and what offers genuine insight and, within the ever-shifting horizons of the ephemeral, daring to experiment with perspective and point of view in order to sustain, or perhaps to regain, the sense of self that the very prevalence of the popular puts at risk. 


\section{Bibliography}

Crary, J. (1990), Techniques of the Observer. On Vision and Modernity in thge N ineteenth Century, C ambridge, M ass., M IT Press.

H EIBERG, J. L. (1843), «Litterær Vintersæd» in Intelligensolade II. 24.

- (1861), Prosai ske Skrifter, Copenhagen, Reitzel. Vol. 4.

H ERTZ, H . (1842), «Et Par O rd om K ritiken over D yrehavscenen "Perspectivkassen" in Intelligensbladel. 8.

KIRM M SE, Bruce H . (1996), Søren Kierkegaard Truffet, Copenhagen, Reitzel.

PAT TISO N, G . (1998), Poor Paris! Kierkegaard's Critique of the Spectacular City, Berlin: Walter de Gruyter.

ZeRLAN G, M. (1995), The City Spectacular of the Nienteenth Century, Copenhagen, Center for Urbanitet og ÆEstetik, Arbejdspapir 9. 